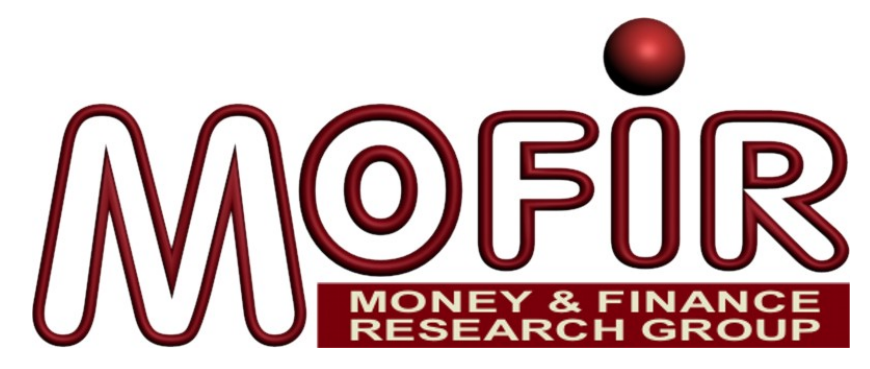

\title{
What Determines the Size of Bank Loans in Industrialized Countries? The Role of Government Debt
}

\author{
Riccardo De Bonis \\ Bank of Italy \\ $M o F_{I} R$ \\ Massimiliano Stacchini \\ Bank of Italy
}

MoFiR working paper $n^{\circ} 39$

April 2010 


\title{
WHAT DETERMINES THE SIZE OF BANK LOANS IN INDUSTRIALIZED COUNTRIES? THE ROLE OF GOVERNMENT DEBT
}

\author{
by R. De Bonis ${ }^{*}$ and M. Stacchini*
}

\begin{abstract}
Given the importance of banking intermediation, we investigate the determinants of the size of bank loans in 18 OECD countries in the period 1981-1997. The aim of the paper is to show that the ratio of government debt to GDP has a negative effect on the level of bank credit. Second, countries with a German legal origin have higher ratios of loans to GDP than common law countries. Our results are robust to including such variables in the regressions as per capita GDP, stock market capitalization, the banking reserve requirement, the level of inflation and its volatility, openness to trade and the use of different econometric methods.
\end{abstract}

JEL classification: G21; G18; C23.

Keywords: bank loans, government debt, financial repression, legal origin of finance.

\section{Contents}

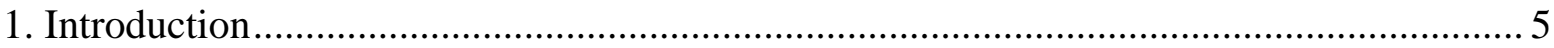

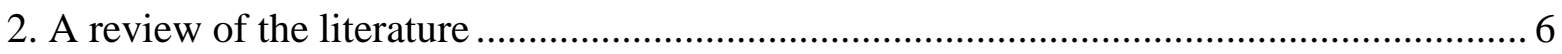

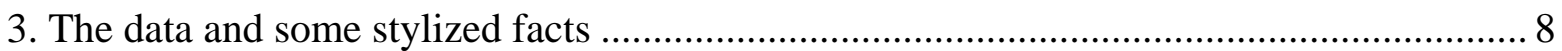

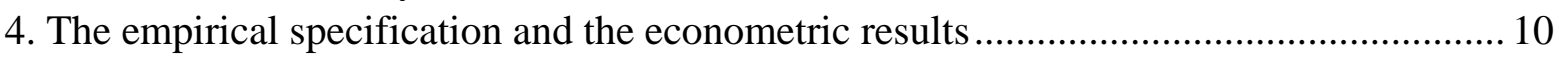

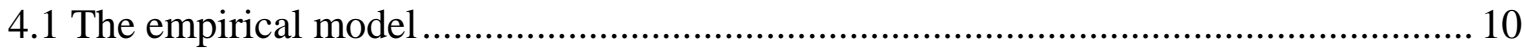

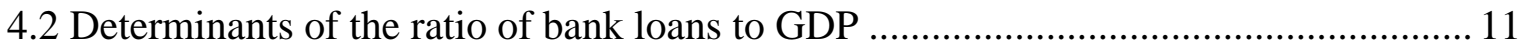

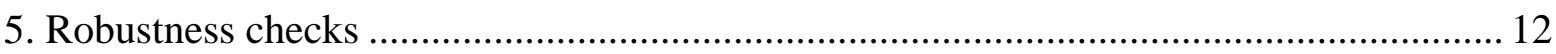

5.1 Do annual data regressions replicate the five-year average statistics results? .............. 12

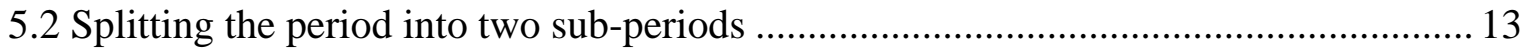

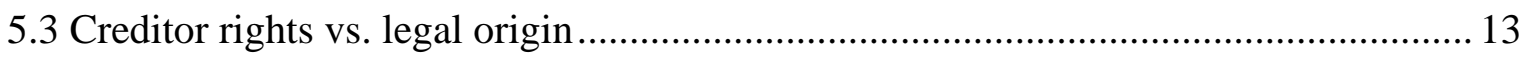

5.4 Do results survive if corporate bonds are included in the picture ? ............................. 15

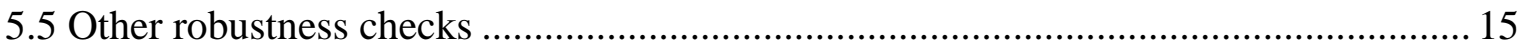

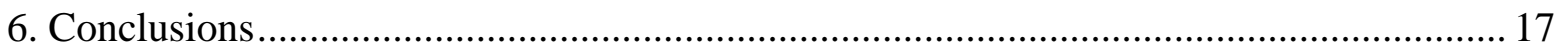

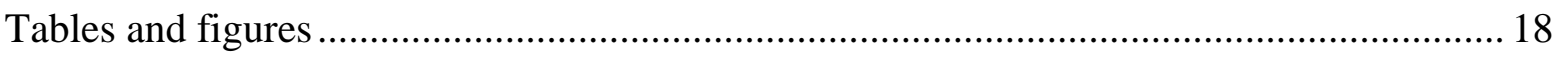

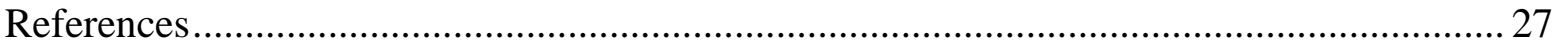

\footnotetext{
${ }^{*}$ Bank of Italy, Economics, Research and International Relations.
} 


\section{Introduction ${ }^{1}$}

Banks are a key element of financial structures all over the world, contributing to the financing of the economy and the management of the payment system. But why are banks more important in some countries and less so in others? In 2004 the ratio of loans to GDP was around 46 per cent in the US, 77 per cent in France and 100 per cent in Germany. The ratio of deposits to GDP was 40 per cent in the US, 68 per cent in France and 86 per cent in Spain.

Different strands of literature studied how the level of bank loans is influenced by economic and institutional variables. Since the 1960s the financial repression approach rationalized the restrictions that affected the financial systems of industrialized countries (McKinnon, 1973; Shaw, 1973). These studies refer to policy instruments - such as high reserve requirement, implicit taxes levied through inflation, explicit taxation, issues of government bonds - that might reduce the size of banking systems. On the contrary, path dependency theories of financial development stress the role of legal origin as the central factor driving the cross-country differences we observe today (La Porta et al, 1997). The idea that legal origin is the major force explaining financial structures has been criticized as being excessively mechanistic. Financial systems change because of the evolution of the real economies and new political choices. For example Rajan and Zingales (2003) showed how financial markets in civil law countries were reversed throughout the last century and start to recover only at the end of the 1980s. Other authors state antagonism between banks and stock markets. This is a very old argument whereas other studies postulate a positive nexus between banks and equity markets.

The goal of this paper is to present new evidence on the determinants of bank loans in OECD countries, discriminating between the different factors by placing them in a general empirical model. The issue we address has not only a theoretical but also a policy relevance. If factors that limit bank development are detected, political authorities may introduce reforms to foster bank credit, whose link with economic growth has been established by many

\footnotetext{
${ }^{1}$ We would like to thank Giovanni Ferri, Silvia Magri, Franco Peracchi, Enrico Perotti, Lisa Rodano, Federico Signorini, Damiano Silipo, Robert Waldmann and two anonymous referees for discussions and helpful comments on previous versions of this paper. We also thank the participants at seminars held at the Universities of Ancona, Bari, Cassino and Ferrara, at the XIV International "Tor Vergata" Conference on Banking and Finance, Rome, 5-7 December 2005 and at the 39 ${ }^{\text {th }}$ Annual Conference of the Money Macro and Finance Research Group, 12-14 September 2007, held at the University of Birmingham. The views are those of the authors and do not necessarily reflect those of the Bank of Italy.
} 
contributions. As far as we know, our new insight is the negative effect of government debt on bank loans.

While most of the literature concentrates on cross-sections, we present a panel analysis of the main OECD countries in the period 1981-1997. Cross-sections for large samples of heterogeneous countries run the risk of not taking into account unobservable factors that may influence the results. Developed countries are more homogeneous and therefore easier to compare.

The paper is divided into 6 sections: the following Section 2 reviews the literature; Section 3 presents the data and introduces some stylized facts; Section 4 illustrates the empirical specification and comments on the econometric exercises; Section 5 contains some robustness checks; and Section 6 concludes.

\section{A review of the literature}

Our paper is connected to various strands of the literature. A first link is with the theory of financial repression. This approach emphasizes a supply side aspect of financial development: governments may repress the size of the financial and banking sectors to raise revenues from alternative channels that lie under their control. Financial repression artificially increases the private sector's demand for those assets that are the basis of implicit taxes, e.g. the monetary base and the public debt. By the second half of the 1960s, regulations, taxes, qualitative and quantitative controls, often introduced to pursue monetary policy goals, made it difficult for financial intermediaries to fulfil their technological potential (Roubini and Salai-Martin, 1995). These measures shrank the financial systems of many countries (Battilossi, 2003). Here we review some of the contributions on these subjects.

Following Fisher's ideas on debt deflation, Boyd et al (2001) assess that inflation causes lower rates of return on loans, thus leading to reduced credit. Smaller real returns can not only decrease the availability of financing but also draw lower quality borrowers into the pool of credit seekers. The authors find a negative relationship between inflation and banking sector size.

There are links between inflation, reserve requirement and government bonds. Brock (1989) considers not only the inflation tax levied on currency but also that on banks' noninterest bearing reserves. In addition, regulation of banks' portfolio composition is a complementary instrument of financial repression. The government may impose portfolio constraints by setting public debt securities as the only assets eligible for meeting banks' requirements: as a consequence banks' resources are channeled towards the purchase of 
government bonds. Further, the government may impose credit ceilings as demonstrated by many industrialized countries in the 1970s. Giovannini and De Melo (1991) explain how nominal interest rate ceilings combined with controls on international flows may generate an artificially low cost of domestic funding for the government and consequent revenues from financial repression. However the link between fiscal policy and banking is not entirely clear. Studying the Italian case, Piluso and Ricciuti (2008) find evidence of pro-cyclical behaviour as regards public spending, taxes and bank variables, even if the causal connections are not investigated.

Our paper also looks at the law and finance view. This approach emphasizes the idea that early institutions and arrangements persist over time and determine current outcomes. The mechanism rests on two points: on the one hand, the basis of finance is the protection of investor and creditor rights; on the other hand, the legal origin of countries is the source of this basis. Legal systems are classified into four categories of origin: Anglo-Saxon, French, German and Scandinavian. They emerged in previous centuries, spreading abroad through conquest and imitation and can explain the differences in investor protection, contracting environment and financial development that countries exhibit today. La Porta et al (1997) show that countries with higher shareholders rights and common law traditions, by and large nations of Anglo-Saxon legal origin, have relatively larger financial markets. The legal approach has been criticized because it overlooks structural breaks in history. Beck et al (2003a) compared the legal traditions paradigm with the "adaptability channel of law": the authors find that legal origin matters for financial development because legal traditions differ in their ability to adapt efficiently to evolving economic conditions. They conclude that in terms of adaptability the German system is closer to the common law than the French legal system. We will come back to this issue of the nature of the German legal system later on.

Other scholars criticized the legal origin approach, underlining the role of interest groups changing over time in explaining cross-country differences in financial systems. Rajan and Zingales (2003) say that preferences of influential interest groups were implemented through the last century by the choice of opening to trade: they show how both in 1913 and in 1997, for any level given of demand, financial development was higher in countries that were more open to trade. ${ }^{2}$ The idea is that international competition weakens the incumbents' opposition to financial development. Quy-Toan Do and Levchenko (2004) provide empirical evidence that trade openness affects the financial systems of countries in a non linear way:

\footnotetext{
${ }^{2}$ Alcalà and Ciccone (2003) show how trade openness was a robust determinant of economic growth in the period 1960-1996.
} 
among developed countries trade promotes financial systems while it has an opposite effect among the poorer ones. Chinn and Ito (2006) focus on the effects of capital account liberalization on financial growth and conclude that financial openness matters only when a threshold level of legal and institutional development has been attained.

In Section 3 we present our empirical strategy.

\section{The data and some stylized facts}

We examine the effects of forms of financial repression and legal origin on bank loans, controlling for stock market capitalization, per capita income and other indicators. We use both contemporaneous variables (such as the reserve requirement and public debt), lagged variables (such as per capita GDP) and time-invariant variables (such as legal origin) referred to 18 OECD countries. The analysis is based upon data originally recorded at an annual frequency, over the period 1981-1997. We chose this time interval because the first composition of the euro area was defined in 1998 and this institutional break might have affected both the behaviour of private credit and its statistical definition. ${ }^{3}$

With regard to our dependent variable, we use the definition adopted by Levine and Zervos (1998) and Levine et al (2000), i.e. the credit granted by the banking system to the private sector, relative to GDP.

Moving to the independent variables, financial repression is measured through different indicators. The reserve requirement is proxied by the ratio of a bank's liquid reserves to its assets. Inflation rates are measured as annual growth rates of the consumer price index. Inflation volatility, measured by the annual standard deviation of the monthly inflation rate, might also affect credit. Public debt is measured by the gross general government debt as a percentage of GDP. It is difficult to collect statistics on other financial repression instruments, such as quantitative ceilings or controls on deposit and lending rates. Moreover most of these measures were gradually suppressed in OECD countries in the 1980s.

Legal origin is considered using the dummies introduced by La Porta et al (1997). The same source was exploited to assess the level of creditor rights protection. Trade openness is measured with the index suggested by Rajan and Zingales (2003), i.e. the sum of exports and imports of goods and services as a share of GDP.

\footnotetext{
${ }^{3}$ The creation of the euro area implied a new definition of many items of bank balance sheets in member states. Moreover in recent years securitization has made the comparison of bank credit in different countries more difficult.
} 
According to a large, though still controversial, body of literature, there is a link between economic growth and finance. While the direction of causality is difficult to establish, the predominant empirical finding is that financial development causes economic growth (for a survey, see Levine, 2003). There is also an opposing view that was probably initiated by Joan Robinson's claim that "finance follows". In this interpretation the structure of the economy determines the types of intermediaries that are best suited to industrial firms. Allen et al (2006) show that financial institutions and markets develop in response to the needs of firms and the characteristics of the real economy. We take this debate into account by using per capita GDP as a proxy of the demand side schedule which might influence the equilibrium level of bank credit. Per capita income is measured in terms of purchasing power parity.

Finally, other studies look at financial systems emphasizing the differences between bank-based and market-based countries. This approach implies that banks and markets are substitutes: households may prefer to invest in deposits rather than in shares; firms may favour shares over bank loans. In a different perspective, stock market capitalization may promote banking activity if banks and markets play a complementary role (Levine and Zervos, 1998). In this view both intermediaries and markets matter for growth (see Demirgüç -Kunt and Levine, 2001, for a synthesis). Given the existence of different opinions, we control how stock market capitalization, as a share of GDP, is linked to banking intermediation.

Table 1 reports the data definition and the sources of the statistics, while Table 2 lists the countries we selected, mainly on the basis of the available long term time series. Table 3 presents some descriptive statistics. Over all periods and all countries, the average ratios of loans to GDP is 0.71 . As indicated by minimum and maximum values, there are marked differences across countries and years for both bank loans and explanatory variables.

Figure 1: Private Credit (as a share of GDP, 1981-1997) in 18 OECD countries

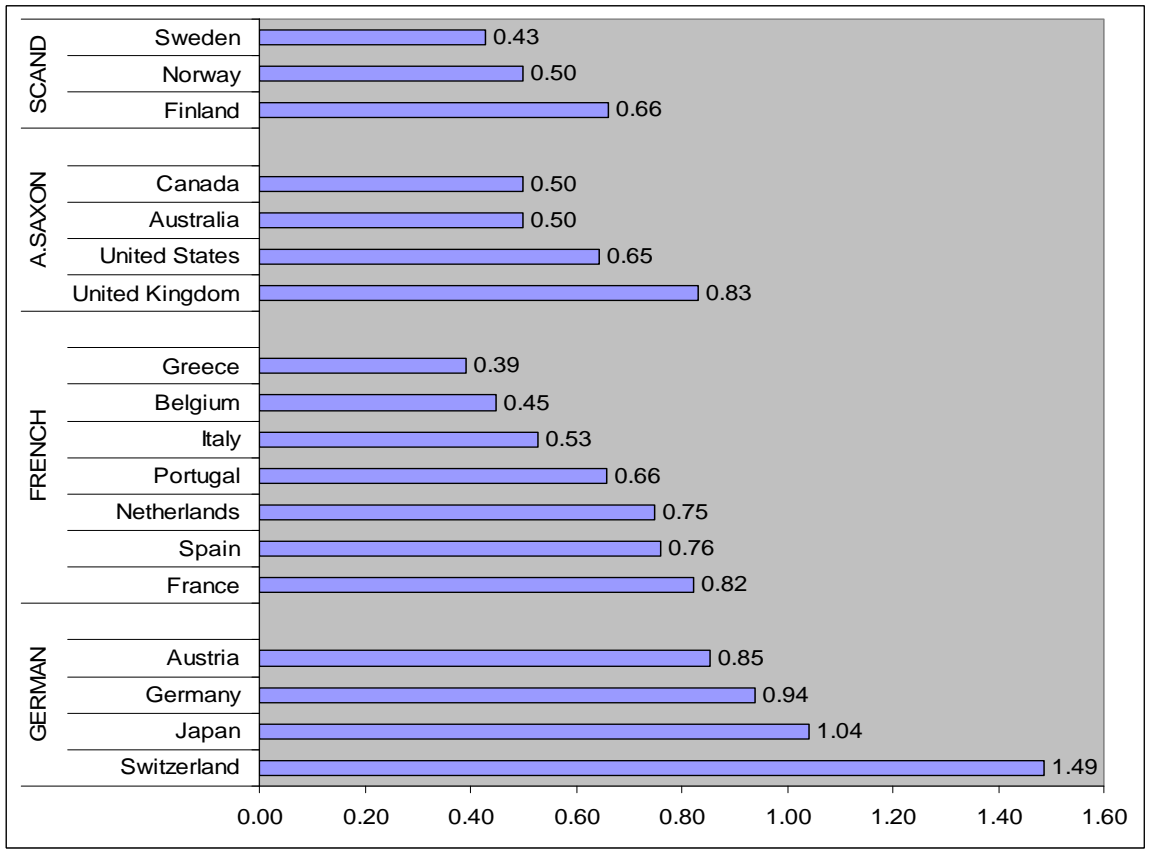


Figure 1 shows the link between countries’ private credit and legal traditions. Banking development is substantially greater in the German origin group than in countries with an Anglo-Saxon legal tradition. Further, all Scandinavian countries are located below the average size. This evidence is confirmed by the correlation matrix (Table 4), which shows a positive association between banking development and countries belonging to the German legal tradition while a negative correlation is detected for Scandinavian countries. The matrix also shows a negative correlation between government debt and the size of bank loans. Negative linkages are observed for bank credit and either inflation rates or reserve requirement. Further, there is a positive association between bank credit, on the one hand, and both stock market capitalization and per capita income, on the other.

In the following section we turn to multivariate regressions.

\section{The empirical specification and the econometric results}

\subsection{The empirical model}

The panel nature of the dataset is exploited through a static model specified as:

$$
\operatorname{priv}_{i t}=\alpha+\beta X_{i t}+\eta_{i}{ }^{+} \varepsilon_{i t}
$$

where priv $_{i t}$ are loans to the private sector, the vector $X_{i t}$ contains time-varying determinants (such as financial repression instruments, per capita GDP and stock market capitalization) while the term $\eta_{i}$ captures "path dependency" time-invariant country components.

We followed the standard practice of taking five-year averages to remove the effects of the business cycle from the analysis (see Islam, 1995). As a further control, we estimated our models over the original annual database (see paragraph 5.1). To avoid the endogeneity issues associated with reverse causality between banking activity, on the one hand, and per capita income and stock market capitalization, on the other, we specified those explanatory variables also through lagged terms. ${ }^{4}$ In such a way they are predetermined with respect to the dependent variable.

\footnotetext{
${ }^{4}$ When we investigate five-year average statistics, those explanatory variables are instrumented through fiveyears average lagged terms. On the contrary, when annual data are analysed, the variables are instrumented through one-year lagged terms.
} 
Cross-country heterogeneity - not captured by financial repression time-varying components - was taken into account through legal origin dummy variables, the first difference estimator, or by estimating both random and fixed effect models ${ }^{5}$.

\subsection{Determinants of the ratio of bank loans to GDP}

In studying the determinants of the credit granted by the banking system to the private sector, as a share of GDP, we follow a step-by-step procedure, starting from a simple model and then adding new variables. Overall we present seven different regressions (Table 5). Beginning with the financial repression variables, the inflation rate sometimes has a negative impact on banking loans, but the coefficients are never significant. Moreover the volatility of inflation does not affect the ratio of credit to GDP. The coefficient of the reserve requirement has a negative sign but it is significant only in two regressions. We cannot support the results of Haslagh and Koo (1999) that the reserve requirement has a negative impact on banking business.

On the contrary, government debt has a negative and statistically significant influence on the ratio of loans to GDP. A 10 per cent increase in the government debt to GDP ratio is expected to lower credit granted to private sectors by 3 (regression 2) or 5 (regression 7) percentage points, respectively. Our result might reflect two similar and interdependent phenomena. According to the public finance approach to financial repression (Giovannini and De Melo, 1991; Battilossi, 2003; Roubini and Sala-i-Martin, 1995), issuing government securities is a way for the State to collect revenues, especially when the proceeds from legal taxation are difficult or costly to obtain, and banks find government securities a good investment. The second interpretation is a typical crowding out effect: in countries where the government has a large involvement in the economy, greater shares of bank credit may flow to State-owned firms, reducing the loans to the private sector. Our results are consistent with those obtained by Hauner (2008), who finds a negative link between public debt held by banks and financial development in middle-income countries.

While the financial repression literature brings into prominence the distortions that affected the banking systems since the 1960s, the legal origin theory emphasizes an older historical derivation of financial systems. Our exercises show that a share of cross-country variability is captured by the legal origin components. The significance of the legal origin variables is seen both in regression 6 (where individual random components are allowed) and

\footnotetext{
${ }^{5}$ In general terms, when cross-country heterogeneity - not accounted for by time-varying variables - is captured by legal origin of countries, pooled estimators with legal dummies are more efficient than fixed effect models.
} 
in regression 7 (where legal origin captures all the variability not accounted for by timevarying determinants). Countries based on German or French law have greater ratios of loans to GDP than common law countries. The German origin effect is the strongest. German origin countries have around 50 percentage points higher ratios of private credit to GDP with respect to the common law countries, while French origin countries have around 30 percentage points greater ratios of loans to GDP with respect to the common law countries. The role of legal origin in influencing capital market development has been recognized by Beck et al (2003a), even if associated with countries' initial endowments. While La Porta et al (1997) state that common law countries are more favourable to financial development, we find that German and French laws lead to higher ratios of loans to GDP. This conundrum is examined in paragraph 5.3.

Moving on to the control variables, per capita income has a positive impact on the ratio of loans to GDP. This is true using contemporaneous per capita income (regression 2 and 4) while the coefficients are positive but not significant using lagged per capita income in fixed and random effect models (regressions 3 and 5). When legal origin dummies are added to the random effect model (regression 6), we obtain similar results.

The econometric exercises of Table 5 also show that contemporaneous stock market capitalization has a positive but not statistically significant influence on the loans to GDP ratio, while predetermined stock market capitalization has a positive and significant coefficient in the random effect model (regression 5). Results are confirmed when legal origin dummies are added to the random effect and pooled models (regressions 6 and 7). This positive nexus confirms the hypothesis of complementarity between stock market capitalization and private credit highlighted in Levine and Zervos (1998).

Now we turn to some robustness checks of our econometric exercises.

\section{Robustness checks}

\subsection{Do annual data regressions replicate the five-year average statistics results?}

To increase the efficiency of our estimates, we run a further nine regressions by exploiting annual statistics (Table 6). We consider the same seven regressions of Table 5 plus two other exercises that include yearly time dummies. The estimated parameters confirm the previous results. Government debt maintains its negative and significant influence on the ratio of loans to GDP. A move from the sample mean of 62 per cent to a ratio of 52 per cent is associated with a 3.5 (regressions 2 and 3), or 5 (regressions 8 and 9) percentage points 
increase in the loans to GDP ratio. Current inflation, its volatility, and the reserve requirement do not influence bank credit. The legal tradition confirms its role in explaining differences in the variability of banking business across countries: compared with common law countries, German and French legal origins are associated with higher ratios of loans to GDP. The German legal tradition dummy has the largest coefficients. Per capita GDP and stock market capitalization maintain a positive and often significant impact on the ratio of outstanding loans to GDP.

\subsection{Splitting the period into two sub-periods}

Banking deregulation and liberalization were much stronger in the 1990s than in the 1980s. European directives liberalized banking markets but the same process also took place in other OECD countries such as the US. ${ }^{6}$ There were also changes in inflation, the reserve requirement, government debt and capital account rules moving from the 1980s to the 1990s. For this reason we split our sample into two periods, 1981-1989 and 1990-1997 to search for possible breaks in the determinants of the ratio of credit to GDP. The results, given in Tables 7 and 8, confirm our previous results. Government debt has a negative influence on private credit and the positive sign of German legal origin is confirmed. As expected, the effect of the government debt to GDP ratio is stronger when the analysis is carried out over the period 1981-1989, as shown by the larger coefficients. In this period, countries which reduce the government debt to GDP ratio by 10 percentage points, are expected to raise credit to GDP ratio by 5.5 percentage points (see regressions 6 and 7) while for the period 1990-1997, the same decrease in government debt is associated with a rise in the dependent variable by 4 percentage points.

\subsection{Creditor rights vs. legal origin}

In the previous paragraphs we found that the law and finance approach provides some insights to explain the size of bank loans in OECD countries. We now scrutinize this effect more closely, looking at the degree of protection of creditors as a determinant of banking development. In their aggregated indebtedness regressions over 39 countries, La Porta et al (1997) found significance for a creditor rights term. This indebtedness measure includes private sector bank debt and outstanding non-financial bonds. As in the previous paragraphs

\footnotetext{
${ }^{6}$ On the transformation of the European banking system see Gual (1999), Belaisch et al (2001), Dermine (2000) and (2003). On the American banking system see Berger et al (1995) and Bernard and Bisignano (2006).
} 
we concentrate on the determinants of bank loans because firms' bond issues respond to different motivations from the raising of bank credit (see paragraph 5.4 on firms' securities issued). Djankov et al (2007) found that stronger legal rights for creditors are associated with a higher level of private credit, running cross-section regressions for a set of 129 countries. On this basis, we investigate the linkage between creditor rights and the ratio of loans to GDP in our sample of OECD countries.

The creditor rights index has a positive effect on the ratio of bank loans to GDP (Table 9) but significance is only obtained when the legal origin dummies are left out of the model, probably because of a positive correlation between creditor rights and the German legal origin dummy. The signs and the significance obtained in the previous paragraph for the other regressors also remain unchanged using five-year average statistics (the results are not given here).

To sum up, we find that the German legal tradition leads to larger banking systems than the Anglo-Saxon and Scandinavian ones. Our conclusion is different from the typical results of the law and finance theory, which links the Anglo-Saxon legal origin to greater financial systems. La Porta et al (1997) stated that:

“[...] indebtedness is even higher in the German civil law countries - also sometimes described with bank-focused financial systems. [...] low rights line up with small markets when we compare French and English origin but German civil law countries are somewhat of a mystery. ${ }^{7}$

It is possible to reconcile our results with the law and finance view by observing that while we look at the determinants of bank credit, La Porta et al study the determinants of different notions of finance, i.e. stock market capitalization or bank loans plus bonds issued by firms. Our empirical results show that there is no German mystery: the German legal origin leads to more bank loans, which are an important source of external finance for firms. This evidence is compatible with Gerschenkron's (1962) thesis on the importance of the universal banks, not the stock market, for the economic growth of Germany and the other countries where this model of intermediary has spread.

\footnotetext{
${ }^{7}$ According to the same authors, a possible explanation is suggested by Rajan and Zingales (1995), who find that German companies have high overall liabilities, though not necessarily high debt per se.
} 


\subsection{Do results survive if corporate bonds are included in the picture?}

The size of bank loans might be influenced by firms' bond issues. One might argue that bank credit is more important where firms' securities issues are smaller (see Fink et al, 2005). To study the relevance of corporate bonds, we included in the model the ratio to GDP of bonds issued by non-financial corporations. For 13 OECD countries data on corporate bonds are available in a time-series format. The econometric exercise (Table 10) shows that the corporate securities coefficient is never significant. The introduction of firms' bonds does not affect the previous determinants of the ratio of credit to GDP.

\subsection{Other robustness checks}

Here we discuss another four robustness checks of our regressions (for the sake of brevity the results are not given here but are available upon request).

First, Perotti and Von Thadden (2005) argue that in many countries the middle classes experienced the post-World War I inflationary shocks and their wealth endowments were seriously damaged; by consequence these classes turned toward more protected bank-oriented systems. Therefore, one should find a positive link between past inflation and the current weight of banks. We built an indicator of the post-World War I inflationary shocks, by averaging the annual growth rates of the consumer price index over the period 1910-1950 in some countries where historical statistics are available (see Mitchell, 2003). Inflationary shocks are statistically significant when there are no other independent variables. When we introduce other regressors - such as government debt and legal origin - past inflationary shocks lose their power to explain the current ratio of loans to GDP. We were not able to find a positive link between past inflationary shocks and current banking business.

Second, as seen in the review of the literature, some authors claim a positive connection between trade openness and banking development. Our results show that in most cases trade openness has a negative effect on bank loans but the coefficients are rarely statistically significant. Our findings do not support Rajan and Zingales’s (2003) or Quy-Toan Do and Levchenko's (2004) views that there is positive linkage between trade and the size of financial systems.

Third, in the last few years some scholars improved the measurement of bank regulation and supervision indicators in order to understand national characteristics of banking business (see Barth et al, 2006). Exploiting a dataset created by the World Bank for many countries, these authors analyse how banking intermediation is influenced by measures 
such as entry barriers and competition regulation variables, restrictions on banking business, separation between banking and commerce, capital ratios, deposit insurance, official supervisory action variables, market discipline and transparency. This line of research is very interesting, but information on banking regulation and supervision is available in the form of cross-section statistics and refers only to very recent periods, while in this paper we study the development of banking loans over two decades. A harmonized picture of banking regulation is not available for the 1980s. For these reasons, the World Bank cross-section database is not used in our paper, even if we are aware that regulation is an important determinant of banking intermediation. Moreover, some variables used in the banking regulation approach, e.g. branching restrictions, are common to the financial repression theory. Pagano and Volpin (2001) claim that banking regulation is an example of where political factors are important, quoting the case of branching limits. Branching may be interpreted as an instrument to repress the geographical reach of banks. We use the ratio of branches to population in 1980 or 1985 as a determinant of the ratio of credit to GDP; we consider the lagged values of branches to avoid endogeneity issues with the level of loans. In our regressions, banking branches in 1980 (or 1985) are not significant to explain the ratio of loans to GDP in the years 1981-1997.

Fourth, we verified if the negative link between government debt and private credit survives after controlling for the importance of the State in the ownership of banks. The test consists of two regressions and makes use of statistics reported by La Porta et al (2002) for the years 1970 and $1995 . .^{8}$ In the first test, a term capturing State ownership of banks is included as a determinant of private credit in an OLS equation running over a cross-section of statistics for $1995 .{ }^{9}$ In the second test, a time-invariant term on State ownership of banks, as observed in 1970, is included as a determinant of private credit in a set of models for panel data (random effect, OLS with time-dummies, pooled regression). All the regressions show that government debt maintains a negative and significant linkage with private credit, even controlling for State ownership of banks. The signs and significance of the parameters mimic those estimated in the analysis of the previous sections. The coefficient for State ownership of banks is mainly negative but not statistically significant and does not affect the sign and the significance of government debt.

\footnotetext{
${ }^{8}$ Other statistics on State ownership of banks are provided by Barth, Caprio and Levine on the World Bank website, but refer to data collected from 2001 onwards.

${ }^{9}$ Outcomes provided by OLS regressions exploiting a few, i.e. 17, observations referring to OECD countries, are reported by Bleaney (1996).
} 


\section{Conclusions}

Our results show that two driving factors lie behind the differences in the size of bank credit relative to GDP.

First, government securities issues reduce the size of bank loans. A first explanation derives from a public finance perspective: financially repressed economies artificially increase their demand for State securities. Banks find that investing in government bonds is more attractive than granting credit to the economy. According to a second explanation, that does not exclude the first, a high public debt to GDP ratio may correspond to a large weight of the government and connected State-owned enterprises in the economy. In this setting, greater portions of credit are absorbed by governmental institutions and State-owned firms rather than by the private sector. While public debt has a negative impact on bank loans, other financial repression variables, such as inflation, its volatility and the reserve requirement do not show a robust significant effect on the ratio of loans to GDP.

Second, as far as the law and finance theory is concerned, we find that the legal tradition of countries is a significant factor that promotes bank credit. The object of our paper is not the study of the financial systems overall but only of the size of bank loans. Therefore we do not identify the Anglo-Saxon legal origin as the crucial driving variable for the development of credit systems. According to our evidence, the most powerful legal origin is the German one; such a result is compatible with the idea that the German legal system is nearer to the common law tradition than previously stated (see Mayer and Sussman, 2001).

Turning to the control variables, bank credit is often positively linked to stock market capitalization and per capita income, both contemporaneous and in lagged terms. Our empirical results are robust to the use of five-year average statistics or annual data, and to the introduction of firms' securities issued in the model. Finally, we did not find a significant effect of past inflationary shocks, the ratio of branches to population, and trade openness on the ratio of loans to GDP. 
Tables and Figures

Table 1 - Data Definition and Sources

Sources of the statistics (key to abbreviations)

BDL: Beck, Demirgüç -Kunt, and Levine (2003b).

IFS: IMF, International Financial Statistics.

LLSV: La Porta, Lopez-de-Silanes, Shleifer, and Vishny (1997).

WDI: World Bank, World Development Indicators.

BP: OECD, Bank Profitability.

SC: OECD, Statistical Compendium.

Dependent variable

priv: claims on private sector by deposit money banks as a percentage of GDP, BDL.

\section{Independent variables}

res2:

reserve requirement calculated as ratio of domestic currency holdings and deposits with the monetary authorities to claims on other governments, non financial public enterprises, the private sector, and other banking institutions, WDI.

infl: $\quad$ inflation rate calculated as annual growth rate of CPI, WDI.

sdinfl: $\quad$ standard deviation of monthly inflation observations for the year, WDI.

gov_deb: $\quad$ gross government debt as a percentage of GDP, SC.

legor_ge: German legal origin, LLSV.

legor_fr: $\quad$ French legal origin, LLSV.

legor_uk: Anglo-Saxon legal origin, LLSV.

legor_sc: $\quad$ Scandinavian legal origin of country, LLSV.

creditor rights: an index aggregating creditor rights, LLSV. A score of one is assigned when each of the following rights of secured lenders are defined in laws and regulation: there are restrictions, such as creditor consent, for a debtor to file for reorganisation (i); secured creditors are able to seize their collateral once the reorganisation petition is approved (ii); secured creditors are paid first out of the proceeds of liquidating a bankrupt firm, as opposed to other creditors (iii); if management does not retain 
administration of its property pending the resolution of the reorganisation (iv). The index ranges from 0 to 4 .

trade: sum of exports and imports of goods and services measured a percentage of GDP, WDI.

infl_hist: historical inflationary shocks, computed as averages of annual changes of CPI, over the period 1910-1950. Source: Mitchell (2003).

GDPp: $\quad$ per capita GDP (PPP, current international \$), WDI.

stock: $\quad$ stock market capitalisation as a percentage of GDP, BDL.

corpbonds: $\quad$ securities other than shares as a percentage of GDP, issued by non financial corporations, European Central Bank and national financial accounts.

Table 2 - Country list (18 High Income OECD Countries)

1 Australia

2 Austria

3 Belgium

4 Canada

5 Finland

6 France

7 Germany

8 Japan

9 Greece

10 Italy

11 Norway

12 Netherlands

13 Portugal

14 Spain

15 Sweden

16 Switzerland

17 United Kingdom

18 United States 


\section{Table 3 - Descriptive statistics}

Annual data for the period 1981-1997. Priv is the amount of credit granted by the bank system to the private sector (as a percentage of GDP); infl is the annual change in consumer prices; sdinfl is the standard deviation of monthly inflation observations for the year; res2 is the bank liquid reserves to bank assets ratio; gov deb is the gross government debt (as a percentage of GDP); GDPpc is the percapita GDP; stock is the stock market capitalization (as a percentage of GDP): trade is the sum of exports and imports of goods and services (as a percentage of GDP). corpbonds is the ratio of bonds issued by non financial corporations to GDP.

\begin{tabular}{|c|c|c|c|c|c|c|c|c|c|}
\hline & priv & infl & sdinfl & res2 & gov_deb & GDPpc & stock & trade & corpbonds \\
\hline mean & 71 & 0.05 & 0.01 & 5.0 & 62 & 16,564 & 37 & 59 & 11 \\
\hline sd & 30 & 0.05 & 0.01 & 8.1 & 29 & 5,043 & 31 & 29 & 9 \\
\hline $\min$ & 26 & -0.19 & 0.00 & 0.2 & 12 & 6,337 & 0 & 16 & 1 \\
\hline $\max$ & 167 & 0.34 & 0.06 & 81.7 & 144 & 30,123 & 183 & 149 & 30 \\
\hline
\end{tabular}

\section{Table 4 - Correlation matrix}

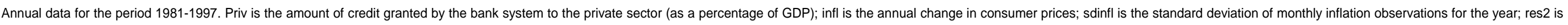

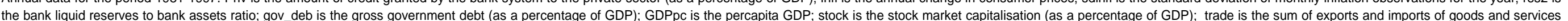
(as a share of GDP); corpbonds is the ratio of bonds issued by non financial corporations to GDP; legal dummies are denoted by the prefix legor_.

\begin{tabular}{|c|c|c|c|c|c|c|c|c|c|c|c|c|c|}
\hline & priv & infl & sdinfl & res2 & gov_deb & GDPpc & stock & trade & corpbonds & legor_ge & legor_fr & legor_uk & legor_sc \\
\hline priv & 1 & & & & & & & & & & & & \\
\hline infl & -0.31 & 1 & & & & & & & & & & & \\
\hline sdinfl & -0.15 & 0.61 & 1 & & & & & & & & & & \\
\hline res2 & -0.26 & 0.49 & 0.34 & 1 & & & & & & & & & \\
\hline gov_deb & -0.36 & -0.14 & -0.12 & 0.02 & 1 & & & & & & & & \\
\hline GDPpc & 0.42 & -0.60 & -0.49 & -0.49 & 0.15 & 1 & & & & & & & \\
\hline stock & 0.50 & -0.39 & -0.27 & -0.39 & -0.03 & 0.59 & 1 & & & & & & \\
\hline trade & -0.11 & -0.08 & -0.07 & -0.15 & 0.36 & 0.02 & -0.11 & 1 & & & & & \\
\hline corpbonds & 0.01 & -0.12 & 0.08 & -0.25 & 0.01 & 0.46 & 0.54 & -0.42 & 1 & & & & \\
\hline legor_ge & 0.68 & -0.30 & -0.17 & -0.19 & -0.21 & 0.22 & 0.16 & -0.12 & 0.67 & 1 & & & \\
\hline legor_fr & -0.24 & 0.33 & 0.19 & 0.45 & 0.45 & -0.36 & -0.40 & 0.31 & -0.24 & -0.43 & 1 & & \\
\hline legor_uk & -0.16 & -0.07 & -0.03 & -0.21 & -0.08 & 0.16 & 0.42 & -0.32 & -0.15 & -0.29 & -0.43 & 1 & \\
\hline legor_sc & -0.27 & -0.02 & -0.03 & -0.14 & -0.27 & 0.05 & -0.12 & 0.07 & -0.27 & -0.24 & -0.36 & -0.24 & 1 \\
\hline
\end{tabular}


Five-year averages for the period 81-85, 86-90, 91-95, 96-00. Dependent variable (priv) is the amount of credit granted by the bank system to the private sector (as a percentage of GDP); linfl is the logarithm of the annual change in consumer prices; Insdinfl is the logarithm of the standard deviation of monthly inflation observations for the year; res2 is the bank liquid reserves to bank assets ratio; gov_deb is the gross government debt (as a percentage of GDP); GDPpc is the per capita GDP; stock is the stock market capitalisation (as a percentage of GDP); legal dummies are denoted by the prefix leg_; the suffix $(1)$ denotes the lagged term of variables; $\left({ }^{*}\right)$ indicates marginal significance at the $5 \%$-level, and $\left({ }^{* \star}\right)$ at the $1 \%$-level; $\quad$ FE and RE indicate fixed effect and random effect models. First diff. is the first difference estimator. (+) point estimates of legal dummies denote differential effects with respect to leg_uk. Robust standard errors are below the estimated parameters.

Dependent variable: priv

\begin{tabular}{|c|c|c|c|c|c|c|c|}
\hline & 1 & 2 & 3 & 4 & 5 & 6 & 7 \\
\hline & $F E$ & $F E$ & $F E$ & First diff. & $R E$ & RE+ & OLS+ \\
\hline linfl & $\begin{array}{l}-9.075 \\
4.95\end{array}$ & $\begin{array}{l}1.966 \\
6.308\end{array}$ & $\begin{array}{l}3.322 \\
4.138\end{array}$ & $\begin{array}{l}-0.430 \\
3.899\end{array}$ & $\begin{array}{l}-0.291 \\
5.105\end{array}$ & $\begin{array}{l}1.511 \\
4.406\end{array}$ & $\begin{array}{l}1.595 \\
4.332\end{array}$ \\
\hline Insdinfl & $\begin{array}{l}-0.162 \\
7.740\end{array}$ & $\begin{array}{l}8.612 \\
4.621\end{array}$ & $\begin{array}{l}\quad 6.291 \\
5.279\end{array}$ & $\begin{array}{l}9.010^{*} \\
3.966\end{array}$ & $\begin{array}{l}2.151 \\
5.531\end{array}$ & $\begin{array}{l}2.556 \\
6.303\end{array}$ & $\begin{array}{l}-4.783 \\
6.095\end{array}$ \\
\hline res2 & $\begin{array}{l}-0.215 \\
0.225\end{array}$ & $\begin{array}{l}-0.170 \\
0.134\end{array}$ & $\begin{array}{l}-0.400 \\
0.295\end{array}$ & $\begin{array}{l}-0.188 \\
0.330\end{array}$ & $\begin{array}{l}-0.423^{*} \\
0.204\end{array}$ & $\begin{array}{l}-0.680 * \\
0.288\end{array}$ & $\begin{array}{l}-0.629 \\
0.436\end{array}$ \\
\hline gov_deb & & $\begin{array}{l}-0.323^{*} \\
0.128\end{array}$ & $\begin{array}{l}-0.278 \\
0.150\end{array}$ & $\begin{array}{l}-0.388^{*} \\
0.162\end{array}$ & $\begin{array}{l}-0.364^{*} \\
0.152\end{array}$ & $\begin{array}{l}-0.444^{\star \star} \\
0.070\end{array}$ & $\begin{array}{l}-0.482^{* *} \\
0.070\end{array}$ \\
\hline GDPpc & & $\begin{array}{l}0.003^{* *} \\
0.001\end{array}$ & & $\begin{array}{l}0.003^{\star \star} \\
0.000\end{array}$ & & & \\
\hline stock & & $\begin{array}{l}0.114 \\
0.120\end{array}$ & & $\begin{array}{l}0.012 \\
0.086\end{array}$ & & & \\
\hline GDPpc_1 & & & $\begin{array}{l}0.002 \\
0.001\end{array}$ & & $\begin{array}{l}0.001 \\
0.001\end{array}$ & $\begin{array}{l}0.001 \\
0.001\end{array}$ & $\begin{array}{l}0.001 \\
0.001\end{array}$ \\
\hline stock_1 & & & $\begin{array}{l}0.206 \\
0.144\end{array}$ & & $\begin{array}{l}0.283^{*} \\
0.130\end{array}$ & $\begin{array}{l}0.408^{*} \\
0.161\end{array}$ & $\begin{array}{l}0.555^{\star \star} \\
0.148\end{array}$ \\
\hline legor_ge & & & & & & $\begin{array}{c}48.903^{\star *} \\
9.176\end{array}$ & $\begin{array}{c}49.002^{\star *} \\
7.798\end{array}$ \\
\hline legor_fr & & & & & & $\begin{array}{l}29.915^{\star *} \\
8.286\end{array}$ & $\begin{array}{c}33.334^{* *} \\
5.898\end{array}$ \\
\hline legor_sc & & & & & & $\begin{array}{l}-4.115 \\
10.467\end{array}$ & $\begin{array}{l}-0.348 \\
9.511\end{array}$ \\
\hline Constant & $\begin{array}{l}41.978 \\
33.414\end{array}$ & $\begin{array}{c}88.273^{\star *} \\
20.973\end{array}$ & $\begin{array}{c}108.132^{\star *} \\
27.347\end{array}$ & & $\begin{array}{l}84.335^{\star *} \\
26.506\end{array}$ & $\begin{array}{l}73.606^{*} \\
36.215\end{array}$ & $\begin{array}{l}38.102 \\
38.177\end{array}$ \\
\hline$N$ & 70 & 68 & 52 & 48 & 52 & 52 & 52 \\
\hline R-squared & 0.21 & 0.30 & 0.34 & 0.27 & 0.43 & 0.85 & 0.86 \\
\hline
\end{tabular}




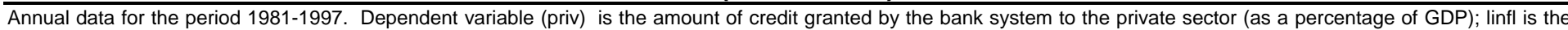

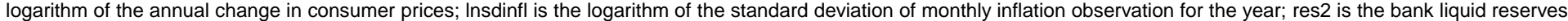

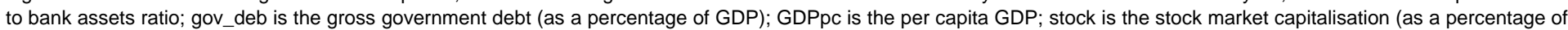

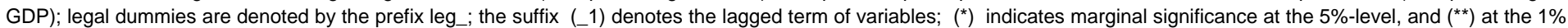

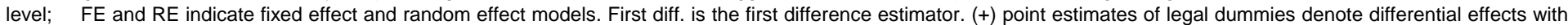
respect to leg_uk. Robust standard errors are below the estimated parameters.

Dependent variable: priv

\begin{tabular}{|c|c|c|c|c|c|c|c|c|c|}
\hline & 1 & 2 & 3 & 4 & 5 & 6 & 7 & 8 & 9 \\
\hline & $F E$ & $F E$ & $F E$ & First diff. & $R E$ & RE+ & OLS+ & $\begin{array}{l}\text { FE ( time- } \\
\text { dummies) }\end{array}$ & $\begin{array}{c}\text { OLS (time } \\
\text { dummies) + }\end{array}$ \\
\hline linfl & $\begin{array}{c}-5.022^{\star *} \\
1.229\end{array}$ & $\begin{array}{l}-0.366 \\
1.298\end{array}$ & $\begin{array}{l}-0.537 \\
1.302\end{array}$ & $\begin{array}{l}0.223 \\
0.500\end{array}$ & $\begin{array}{l}-0.924 \\
1.261\end{array}$ & $\begin{array}{l}-1.334 \\
1.256\end{array}$ & $\begin{array}{l}-3.39 \\
2.125\end{array}$ & $\begin{array}{l}0.544 \\
1.63\end{array}$ & $\begin{array}{l}-1.992 \\
3.108\end{array}$ \\
\hline Insdinfl & $\begin{array}{l}-1.338 \\
1.903\end{array}$ & $\begin{array}{l}2.425 \\
1.590\end{array}$ & $\begin{array}{l}1.516 \\
1.463\end{array}$ & $\begin{array}{l}0.075 \\
0.356\end{array}$ & $\begin{array}{l}1.426 \\
1.495\end{array}$ & $\begin{array}{l}1.322 \\
1.499\end{array}$ & $\begin{array}{l}0.174 \\
1.812\end{array}$ & $\begin{array}{l}2.765 \\
1.696\end{array}$ & $\begin{array}{l}1.043 \\
2.074\end{array}$ \\
\hline res2 & $\begin{array}{l}-0.879 \\
0.427\end{array}$ & $\begin{array}{l}-0.192 \\
0.198\end{array}$ & $\begin{array}{l}-0.141 \\
0.183\end{array}$ & $\begin{array}{l}-0.308 \\
0.176\end{array}$ & $\begin{array}{l}-0.106 \\
0.185\end{array}$ & $\begin{array}{l}-0.167 \\
0.232\end{array}$ & $\begin{array}{c}0.027 \\
0.294\end{array}$ & $\begin{array}{l}-0.05 \\
0.245\end{array}$ & $\begin{array}{l}-0.093 \\
0.352\end{array}$ \\
\hline gov_deb & & $\begin{array}{l}-0.357^{\star \star} \\
0.113\end{array}$ & $\begin{array}{c}-0.341^{\star *} \\
0.097\end{array}$ & $\begin{array}{l}-0.127^{\star} \\
0.057\end{array}$ & $\begin{array}{c}-0.356^{\star \star} \\
0.091\end{array}$ & $\begin{array}{l}-0.411^{\star *} \\
0.064\end{array}$ & $\begin{array}{l}-0.494^{\star *} \\
0.055\end{array}$ & $\begin{array}{l}-0.473^{*} \\
0.234\end{array}$ & $\begin{array}{l}-0.494^{\star *} \\
0.058\end{array}$ \\
\hline GDPpc & & $\begin{array}{l}0.002^{\star \star} \\
0.000\end{array}$ & & $\begin{array}{l}0.001^{\star \star} \\
0.000\end{array}$ & & & & $\begin{array}{l}0.001 \\
0.003\end{array}$ & $\begin{array}{l}0.001 \\
0.001\end{array}$ \\
\hline stock & & $\begin{array}{l}0.146 \\
0.132\end{array}$ & & $\begin{array}{l}0.013 \\
0.038\end{array}$ & & & & $\begin{array}{l}0.164 \\
0.126\end{array}$ & $\begin{array}{l}0.41^{\text {** }} \\
0.410\end{array}$ \\
\hline GDPpc_1 & & & $\begin{array}{l}0.002^{\star \star} \\
0.001\end{array}$ & & $\begin{array}{l}0.002^{\star \star} \\
0.001\end{array}$ & $\begin{array}{l}0.002^{\star \star} \\
0.001\end{array}$ & $\begin{array}{l}0.001^{*} \\
0.000\end{array}$ & & \\
\hline stock_1 & & & $\begin{array}{l}0.179 \\
0.160\end{array}$ & & $\begin{array}{l}0.202 \\
0.142\end{array}$ & $\begin{array}{l}0.282^{\star} \\
0.142\end{array}$ & $\begin{array}{l}0.441^{\star \star} \\
0.101\end{array}$ & & \\
\hline legor_ge & & & & & & $\begin{array}{c}44.600 * * \\
6.587\end{array}$ & $\begin{array}{c}43.460 \text { ** } \\
4.962\end{array}$ & & $\begin{array}{l}44.649 * * \\
4.648\end{array}$ \\
\hline legor_fr & & & & & & $\begin{array}{c}27.004^{\star *} \\
4.655\end{array}$ & $\begin{array}{c}31.524^{\star *} \\
3.167\end{array}$ & & $\begin{array}{l}30.440 * * \\
3.798\end{array}$ \\
\hline legor_sc & & & & & & $\begin{array}{l}-2.680 \\
7.092\end{array}$ & $\begin{array}{l}-0.253 \\
6.248\end{array}$ & & $\begin{array}{l}-1.124 \\
6.379\end{array}$ \\
\hline Constant & $\begin{array}{c}50.584^{\star *} \\
10.463\end{array}$ & $\begin{array}{c}60.966^{\star \star *} \\
10.37\end{array}$ & $\begin{array}{c}58.607^{\star *} \\
10.642\end{array}$ & & $\begin{array}{c}58.305^{\star \star} \\
11.852\end{array}$ & $\begin{array}{l}39.773^{\star *} \\
11.083\end{array}$ & $\begin{array}{l}31.982^{*} \\
12.896\end{array}$ & $\begin{array}{l}82.509^{*} \\
39.039\end{array}$ & $\begin{array}{l}40.029^{\star} \\
16.903\end{array}$ \\
\hline $\mathbf{N}$ & 291 & 277 & 262 & 253 & 262 & 262 & 262 & 277 & 277 \\
\hline R-squared & 0.15 & 0.39 & 0.42 & 0.32 & 0.43 & 0.80 & 0.82 & 0.40 & 0.83 \\
\hline
\end{tabular}




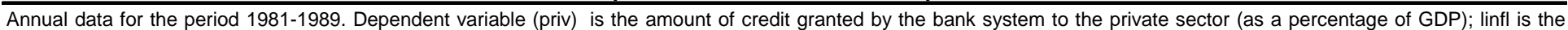

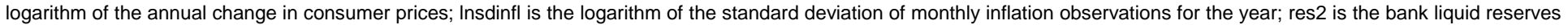

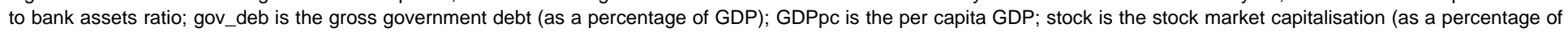

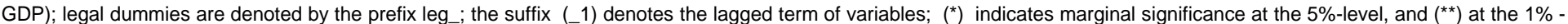

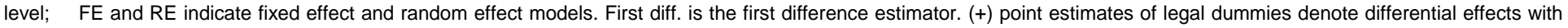
respect to leg_uk. Robust standard errors are below the estimated parameters.

Dependent variable: priv

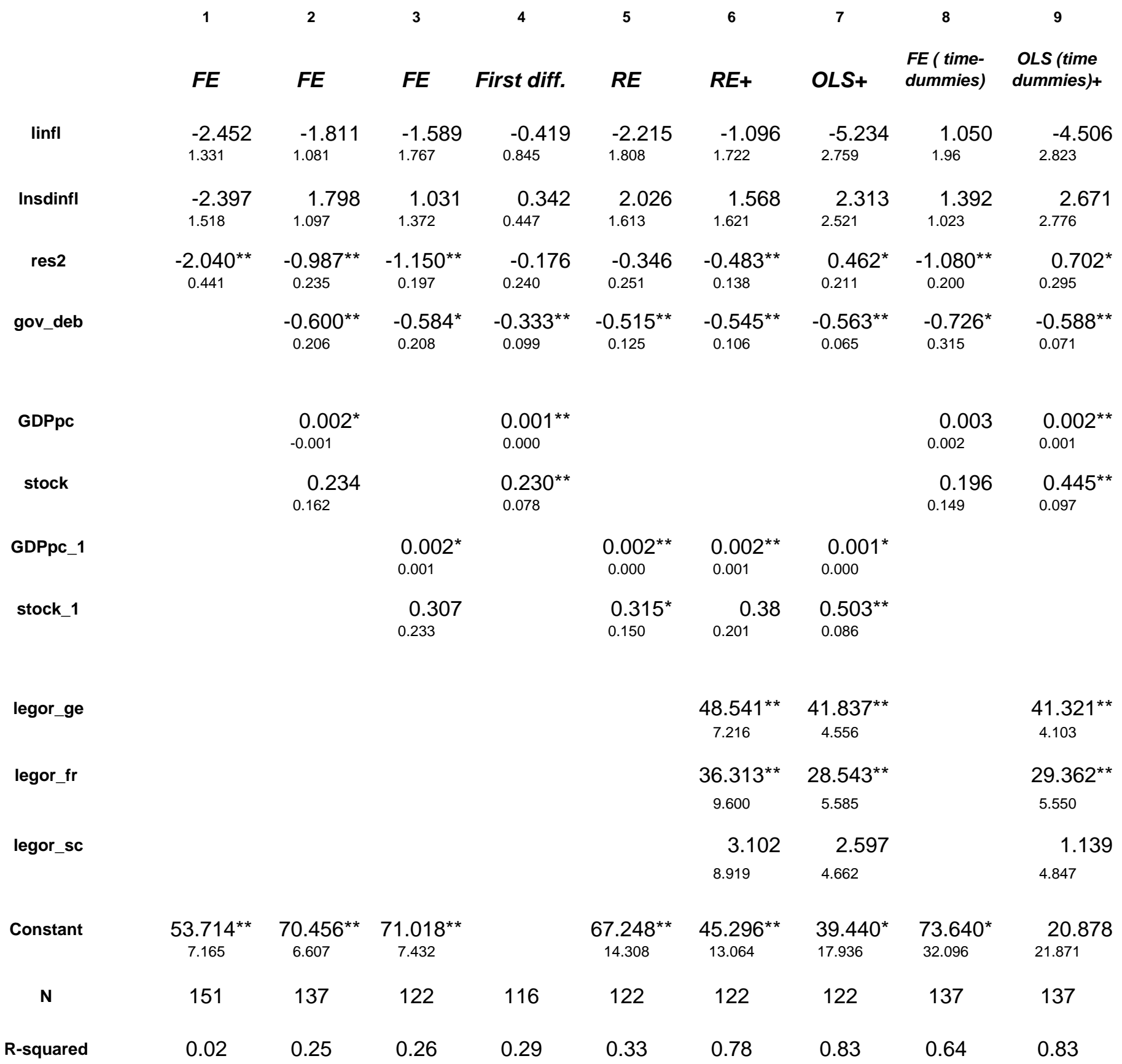


Annual data for the period 1990-1997. Dependent variable (priv) is the amount of credit granted by the bank system to the private sector (as a percentage of GDP); linfl is the logarithm of the annual change in consumer prices; Insdinfl is the logarithm of the standard deviation of monthly inflation observations for the year; res2 is the bank liquid reserves to bank assets ratio; gov_deb is the gross government debt (as a percentage of GDP); GDPpc is the per capita GDP; stock is the stock market capitalisation (as a percentage of GDP); legal dummies are denoted by the prefix leg_; the suffix ( 1$)$ denotes the lagged term of variables; (*) indicates marginal significance at the $5 \%$-level, and $\left({ }^{*}\right)$ at the $1 \%$-level; FE and RE indicate fixed effect and random effect models. First diff. is the first difference estimator. (+) point estimates of legal dummies denote differential effects with respect to leg_uk. Robust standard errors are below the estimated parameters.

Dependent variable: priv

\begin{tabular}{|c|c|c|c|c|c|c|c|c|c|}
\hline & 1 & 2 & 3 & 4 & 5 & 6 & 7 & 8 & 9 \\
\hline & $F E$ & $F E$ & $F E$ & First diff. & $R E$ & RE+ & OLS+ & $\begin{array}{l}\text { FE (time- } \\
\text { dummies) }\end{array}$ & $\begin{array}{c}\text { OLS (time } \\
\text { dummies)+ }\end{array}$ \\
\hline linfl & $\begin{array}{l}0.793 \\
1.522\end{array}$ & $\begin{array}{l}-0.357 \\
0.685\end{array}$ & $\begin{array}{l}-0.201 \\
0.683\end{array}$ & $\begin{array}{l}0.192 \\
0.633\end{array}$ & $\begin{array}{l}-0.363 \\
0.744\end{array}$ & $\begin{array}{l}-0.737 \\
0.729\end{array}$ & $\begin{array}{l}-3.742 \\
2.600\end{array}$ & $\begin{array}{l}1.984 \\
1.361\end{array}$ & $\begin{array}{l}-3.250 \\
3.761\end{array}$ \\
\hline Insdinfl & $\begin{array}{l}-1.281 \\
0.852\end{array}$ & $\begin{array}{l}-1.930 \\
1.011\end{array}$ & $\begin{array}{l}-2.025^{\star} \\
0.847\end{array}$ & $\begin{array}{l}-0.645 \\
0.601\end{array}$ & $\begin{array}{l}-2.059 \star \\
0.848\end{array}$ & $\begin{array}{l}-1.770^{\star} \\
0.786\end{array}$ & $\begin{array}{l}-1.389 \\
1.983\end{array}$ & $\begin{array}{l}-0.972 \\
0.992\end{array}$ & $\begin{array}{l}-0.008 \\
2.359\end{array}$ \\
\hline res2 & $\begin{array}{l}-0.841^{*} \\
0.344\end{array}$ & $\begin{array}{l}-0.625^{\star} \\
0.281\end{array}$ & $\begin{array}{l}-0.536 \\
0.313\end{array}$ & $\begin{array}{l}-0.399 \\
0.261\end{array}$ & $\begin{array}{l}-0.583^{\star} \\
0.280\end{array}$ & $\begin{array}{l}-0.649 * * \\
0.241\end{array}$ & $\begin{array}{l}-0.818 \\
0.423\end{array}$ & $\begin{array}{l}-0.009 \\
0.293\end{array}$ & $\begin{array}{l}-0.985 \\
0.512\end{array}$ \\
\hline gov_deb & & $\begin{array}{l}-0.331^{\star *} \\
0.104\end{array}$ & $\begin{array}{l}-0.361^{* *} \\
0.108\end{array}$ & $\begin{array}{l}-0.011 \\
0.074\end{array}$ & $\begin{array}{l}-0.380^{\star \star} \\
0.110\end{array}$ & $\begin{array}{l}-0.402^{\star \star} \\
0.090\end{array}$ & $\begin{array}{l}-0.441^{* *} \\
0.089\end{array}$ & $\begin{array}{l}-0.771^{\star \star} \\
0.196\end{array}$ & $\begin{array}{l}-0.415^{\star \star} \\
0.088\end{array}$ \\
\hline GDPpc & & $\begin{array}{l}0.002 \\
-0.001\end{array}$ & & $\begin{array}{l}0.000 \\
0.000\end{array}$ & & & & $\begin{array}{l}-0.004 \\
0.002\end{array}$ & $\begin{array}{l}0.000 \\
0.001\end{array}$ \\
\hline stock & & $\begin{array}{l}-0.047 \\
0.07\end{array}$ & & $\begin{array}{l}-0.018 \\
0.047\end{array}$ & & & & $\begin{array}{l}-0.143 \\
0.08\end{array}$ & $\begin{array}{l}0.406^{\star *} \\
0.094\end{array}$ \\
\hline GDPpc_1 & & & $\begin{array}{l}0.002 \\
0.001\end{array}$ & & $\begin{array}{l}0.002 \\
0.001\end{array}$ & $\begin{array}{l}0.002 \\
0.001\end{array}$ & $\begin{array}{l}0.000 \\
0.001\end{array}$ & & \\
\hline stock_1 & & & $\begin{array}{l}-0.082 \\
0.095\end{array}$ & & $\begin{array}{l}-0.038 \\
0.090\end{array}$ & $\begin{array}{l}0.011 \\
0.080\end{array}$ & $\begin{array}{l}0.409 * \star \\
0.109\end{array}$ & & \\
\hline legor_ge & & & & & & $\begin{array}{c}38.313^{\star \star} \\
14.722\end{array}$ & $\begin{array}{c}44.747^{\star *} \\
7.491\end{array}$ & & $\begin{array}{l}47.603^{\star *} \\
6.795\end{array}$ \\
\hline legor_fr & & & & & & $\begin{array}{l}16.238 \\
11.321\end{array}$ & $\begin{array}{c}30.205^{\star \star} \\
6.687\end{array}$ & & $\begin{array}{c}30.301^{* *} \\
6.835\end{array}$ \\
\hline legor_sc & & & & & & $\begin{array}{l}-15.349 \\
13.295\end{array}$ & $\begin{array}{l}-2.627 \\
10.758\end{array}$ & & $\begin{array}{l}-1.754 \\
11.554\end{array}$ \\
\hline Constant & $\begin{array}{l}77.067^{\star * *} \\
6.103\end{array}$ & $\begin{array}{c}63.061^{\star \star} \\
16.988\end{array}$ & $\begin{array}{c}59.464^{\star \star} \\
16.779\end{array}$ & & $\begin{array}{c}59.124^{\star \star} \\
16.062\end{array}$ & $\begin{array}{l}49.997^{*} \\
21.397\end{array}$ & $\begin{array}{l}45.204 \\
23.539\end{array}$ & $\begin{array}{c}205.922^{\star \star} \\
52.897\end{array}$ & $\begin{array}{l}50.107 \\
31.736\end{array}$ \\
\hline $\mathbf{N}$ & 140 & 140 & 140 & 119 & 140 & 140 & 140 & 140 & 140 \\
\hline R-squared & 0.18 & 0.34 & 0.33 & 0.18 & 0.37 & 0.72 & 0.83 & 0.02 & 0.84 \\
\hline
\end{tabular}




\title{
Table 9 - Determinants of loans to GDP ratio in OECD countries: do creditor
} rights matter?

\author{
(annual data)
}

Annual data for the period 1981-1997. Dependent variable (priv) is the amount of credit granted by the bank system to the private sector (as a percentage of GDP); linfl is the logarithm of the annual change in consumer prices; Insdinfl is the logarithm of the standard deviation of monthly inflation observations for the year; res2 is the bank liquid reserves to bank assets ratio; gov deb is the gross government debt (as a percentage of GDP); GDPpc is the per capita GDP. stock is the stock market capitalisation (as a percentage of GDP); cr_rights is an index indicating creditor rights; legal dummies are denoted by the prefix leg_; the suffix ( 1$)$ denotes the lagged term of variables; $\left(^{*}\right)$ indicates marginal significance at the $5 \%$-level, and $\left({ }^{*}\right)$ at the $1 \%$-level; RE indicates random effect model. $(+)$ point estimates of legal dummies denote differential effects with respect to leg_uk. Robust standard errors are below the estimated parameters.

Dependent variable: priv

\begin{tabular}{|c|c|c|c|}
\hline & RE+ & $R E+$ & $R E$ \\
\hline linfl & $\begin{array}{l}-1.734 \\
1.294\end{array}$ & $\begin{array}{l}-1.215 \\
1.252\end{array}$ & $\begin{array}{l}-0.686 \\
1.283\end{array}$ \\
\hline Insdinfl & $\begin{array}{l}1.073 \\
1.133\end{array}$ & & \\
\hline res2 & $\begin{array}{l}-0.159 \\
0.216\end{array}$ & $\begin{array}{l}-0.137 \\
0.225\end{array}$ & $\begin{array}{l}-0.014 \\
0.241\end{array}$ \\
\hline gov_deb & $\begin{array}{l}-0.379 * * \\
0.051\end{array}$ & $\begin{array}{l}-0.377^{\star *} \\
0.054\end{array}$ & $\begin{array}{l}-0.318^{\star \star} \\
0.057\end{array}$ \\
\hline GDPpc_1 & $\begin{array}{l}0.002^{\star \star} \\
0.000\end{array}$ & $\begin{array}{l}0.002^{\star \star} \\
0.000\end{array}$ & $\begin{array}{l}0.002^{\star \star} \\
0.000\end{array}$ \\
\hline stock_1 & $\begin{array}{l}0.280^{* *} \\
0.055\end{array}$ & $\begin{array}{l}0.253^{\star *} \\
0.058\end{array}$ & $\begin{array}{l}0.198^{\star \star} \\
0.062\end{array}$ \\
\hline cr_rights & & $\begin{array}{l}3.471 \\
2.460\end{array}$ & $\begin{array}{l}7.464^{*} \\
3.223\end{array}$ \\
\hline legor_ge & $\begin{array}{l}39.482^{\star \star} \\
5.434\end{array}$ & $\begin{array}{l}35.683^{* *} \\
6.960\end{array}$ & \\
\hline legor_fr & $\begin{array}{c}25.679 * * \\
5.034\end{array}$ & $\begin{array}{c}25.777^{\star *} \\
5.936\end{array}$ & \\
\hline legor_sc & $\begin{array}{l}-2.522 \\
5.543\end{array}$ & $\begin{array}{l}-1.893 \\
6.690\end{array}$ & \\
\hline Constant & $\begin{array}{l}38.397^{* *} \\
6.900\end{array}$ & $\begin{array}{c}28.446^{\star *} \\
7.444\end{array}$ & $\begin{array}{c}36.266^{\star \star} \\
7.779\end{array}$ \\
\hline $\mathbf{N}$ & 251 & 251 & 251 \\
\hline R-squared & 0.69 & 0.70 & 0.35 \\
\hline
\end{tabular}




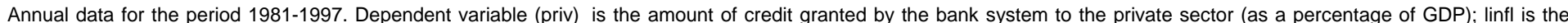

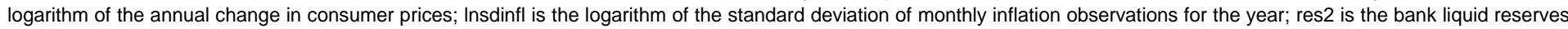

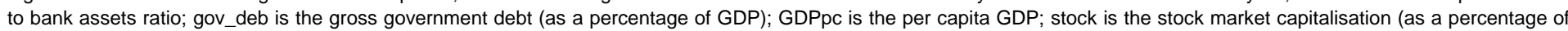

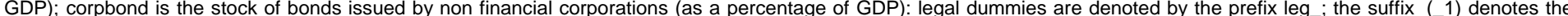

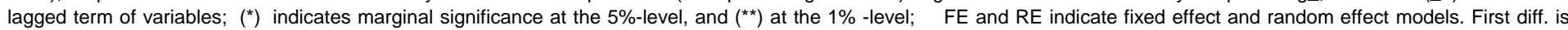
the first difference estimator. $(+)$ point estimates of legal dummies denote differential effects with respect to leg_uk. Robust standard errors are below the estimated parameters.

Dependent variable: priv

\begin{tabular}{|c|c|c|c|c|c|c|c|c|c|}
\hline & 1 & 2 & 3 & 4 & 5 & 6 & 7 & 8 & 9 \\
\hline & $F E$ & $F E$ & $F E$ & First diff. & $R E$ & RE+ & OLS+ & $\begin{array}{l}\text { FE ( time- } \\
\text { dummies) }\end{array}$ & $\begin{array}{c}\text { OLS (time } \\
\text { dummies)+ }\end{array}$ \\
\hline linfl & $\begin{array}{l}-0.429 \\
1.964\end{array}$ & $\begin{array}{l}-0.932 \\
0.764\end{array}$ & $\begin{array}{l}-1.042 \\
0.979\end{array}$ & $\begin{array}{l}0.029 \\
0.830\end{array}$ & $\begin{array}{l}-1.707 \\
1.045\end{array}$ & $\begin{array}{l}-2.947^{*} \\
1.373\end{array}$ & $\begin{array}{l}-4.045 \\
2.737\end{array}$ & $\begin{array}{l}1.270 \\
2.054\end{array}$ & $\begin{array}{l}-0.586 \\
1.926\end{array}$ \\
\hline Insdinfl & $\begin{array}{l}-0.678 \\
0.950\end{array}$ & $\begin{array}{l}-0.510 \\
0.903\end{array}$ & $\begin{array}{l}-0.427 \\
0.799\end{array}$ & $\begin{array}{l}-0.548 \\
0.629\end{array}$ & $\begin{array}{l}-0.494 \\
0.872\end{array}$ & $\begin{array}{l}-0.148 \\
1.013\end{array}$ & $\begin{array}{l}0.639 \\
1.360\end{array}$ & $\begin{array}{l}-0.729 \\
1.158\end{array}$ & $\begin{array}{l}1.002 \\
1.906\end{array}$ \\
\hline res2 & $\begin{array}{l}-0.713^{\star *} \\
0.130\end{array}$ & $\begin{array}{l}-0.473 \\
0.233\end{array}$ & $\begin{array}{l}-0.416 \\
0.248\end{array}$ & $\begin{array}{l}-0.448 \\
0.301\end{array}$ & $\begin{array}{l}-0.498^{*} \\
0.247\end{array}$ & $\begin{array}{l}-0.673^{*} \\
0.331\end{array}$ & $\begin{array}{l}-0.916^{*} \\
0.417\end{array}$ & $\begin{array}{l}0.293 \\
0.403\end{array}$ & $\begin{array}{l}-1.100 * \\
0.423\end{array}$ \\
\hline gov_deb & & $\begin{array}{l}-0.268 * \\
0.111\end{array}$ & $\begin{array}{l}-0.293^{*} \\
0.108\end{array}$ & $\begin{array}{l}0.017 \\
0.092\end{array}$ & $\begin{array}{c}-0.344^{\star \star} \\
0.074\end{array}$ & $\begin{array}{l}-0.388 \text { ** } \\
0.075\end{array}$ & $\begin{array}{c}-0.348^{\star \star} \\
0.058\end{array}$ & $\begin{array}{l}-0.806^{\star \star} \\
0.241\end{array}$ & $\begin{array}{l}-0.331^{\text {** }} \\
0.068\end{array}$ \\
\hline GDPpc & & $\begin{array}{l}0.002 \\
0.001\end{array}$ & & $\begin{array}{l}0.000 \\
0.001\end{array}$ & & & & $\begin{array}{l}-0.007 \\
0.004\end{array}$ & $\begin{array}{l}-0.001 \\
0.001\end{array}$ \\
\hline stock & & $\begin{array}{l}-0.058 \\
0.106\end{array}$ & & $\begin{array}{l}-0.034 \\
0.057\end{array}$ & & & & $\begin{array}{l}-0.119 \\
0.104\end{array}$ & $\begin{array}{l}0.367^{\text {** }} \\
0.073\end{array}$ \\
\hline GDPpc_1 & & & $\begin{array}{l}0.002 \\
0.001\end{array}$ & & $\begin{array}{l}0.002 \\
0.001\end{array}$ & $\begin{array}{l}0.001 \\
0.001\end{array}$ & $\begin{array}{l}0.000 \\
0.001\end{array}$ & & \\
\hline stock_1 & & & $\begin{array}{l}-0.067 \\
0.144\end{array}$ & & $\begin{array}{l}-0.034 \\
0.122\end{array}$ & $\begin{array}{l}0.139 \\
0.107\end{array}$ & $\begin{array}{l}0.382^{* *} \\
0.077\end{array}$ & & \\
\hline corpbonds & $\begin{array}{l}1.616 \\
0.886\end{array}$ & $\begin{array}{l}1.236 \\
0.811\end{array}$ & $\begin{array}{l}1.179 \\
0.762\end{array}$ & $\begin{array}{l}1.357 \\
0.385\end{array}$ & $\begin{array}{l}0.428 \\
0.611\end{array}$ & $\begin{array}{l}0.065 \\
0.545\end{array}$ & $\begin{array}{l}-0.498 \\
0.309\end{array}$ & $\begin{array}{l}0.768 \\
0.794\end{array}$ & $\begin{array}{l}-0.279 \\
0.309\end{array}$ \\
\hline legor_ge & & & & & & $\begin{array}{l}28.939 * \\
13.511\end{array}$ & $\begin{array}{c}30.084^{\star *} \\
5.129\end{array}$ & & $\begin{array}{l}34.923^{* *} \\
4.777\end{array}$ \\
\hline legor_fr & & & & & & $\begin{array}{l}18.632 \\
13.368\end{array}$ & $\begin{array}{c}15.569 * \\
5.935\end{array}$ & & $\begin{array}{l}16.418^{*} \\
6.726\end{array}$ \\
\hline legor_sc & & & & & & $\begin{array}{r}4.692 \\
13.431\end{array}$ & $\begin{array}{l}6.358 \\
5.655\end{array}$ & & $\begin{array}{l}9.424 \\
5.009\end{array}$ \\
\hline Constant & $\begin{array}{c}59.390^{\star *} \\
12.475\end{array}$ & $\begin{array}{l}48.745 \\
23.185\end{array}$ & $\begin{array}{l}46.906 \\
22.990\end{array}$ & & $\begin{array}{c}57.695^{\star \star} \\
21.604\end{array}$ & $\begin{array}{l}54.668 \\
31.132\end{array}$ & $\begin{array}{c}77.449 \star \star \\
24.378\end{array}$ & $\begin{array}{c}306.783^{*} \\
101.521\end{array}$ & $\begin{array}{l}98.929 * * \\
29.776\end{array}$ \\
\hline$N$ & 115 & 115 & 115 & 100 & 115 & 115 & 115 & 115 & 115 \\
\hline R-squared & 0.01 & 0.09 & 0.10 & 0.00 & 0.24 & 0.67 & 0.78 & 0.07 & 0.80 \\
\hline
\end{tabular}




\section{References}

Alcalá, F. and A. Ciccone (2003), "Trade, Extent of the Market, and Economic Growth 19601996," Universitat Pompeu Fabra, Working Papers, No 765.

Allen, F., L. Bartiloro and O. Kowalewski (2006), “Does Economic Structure Determine Financial Structure ?”, mimeo.

Barth, J. R., G. J. Caprio and R. Levine (2006), “Rethinking Bank Regulation: Till Angels Govern”, Cambridge University Press.

Battilossi, S. (2003), “Capital Mobility and Financial Repression in Italy, 1960-1990: A Public Finance Perspective”, Universidad Carlos III De Madrid, Working Paper in Economic History, No 03-06.

Beck, T., A. Demirgüç-Kunt and R. Levine R. (2003a), "Law, Endowments, and Finance”, Journal of Financial Economics, Vol. 70(2), pp. 137-181.

Beck, T., A. Demirgüç-Kunt and R. Levine (2003b), “A New Database on Financial Development and Structure”, World Bank Economic Review, Vol 14, pp. 597-605 - updated in 2008.

Belaisch, A., L. Kodres, J. Levy and A. Ubide (2001), “Euro-Area Banking at the Crossroads”, International Monetary Found, IMF Working Paper, No. 1/28.

Berger, A.N., A.K. Kashyap and J.M. Scalise (1995), "The Transformation of the US Banking Industry: What Long, Strange Trip it's been”, Brookings Papers on Economic Activity, Vol. 26 (2), pp. 55-218.

Bernard, H. and J. Bisignano (2006), "Financial Intermediary Transformation. Risk Absorption, Transfer and Trading in the US Financial System”, in M. de Cecco and G. Nardozzi (Eds.), Banche e finanza nel futuro: Europa, Stati Uniti, Asia, Bancaria Editrice.

Bleaney, M. (1996), “Central Bank Independence, Wage Bargaining Structure, and Macroeconomic Performance in OECD Countries”, Oxford Economic Papers, Vol 48, pp. 20-38.

Boyd, J.H., R. Levine and B.D. Smith (2001), "The Impact of Inflation on Financial Sector Performance”, Journal of Monetary Economics, Vol. 47(2), pp. 221-248.

Brock, P. L. (1989), "Reserve Requirements and the Inflation Tax”, Journal of Money Credit and Banking, Vol. 21(1), pp. 106-221.

Chinn, M. D. and H. Ito (2006), "What Matters for Financial Development? Capital Controls, Institutions, and Interactions”, Journal of Development Economics, Vol. 81(1), pp. 163-192.

Demirgüç-Kunt, A. and R. Levine (2001), “Financial Structure and Economic Growth”, The MIT Press. 
Dermine, J. (2000), "Eurobanking”, in M. Artis, A. Weber and E. Hennessy (Eds.), The Euro. A Challenge and Opportunity for Financial Markets, Routledge International Studies in Money and Banking.

Dermine, J. (2003), “Banking in Europe: Past, Present and Future”, in V. Gaspar, P. Hartmann and O. Sleijpen (Eds.), The Transformation of the European Financial System, European Central Bank, Frankfurt.

Djankov, S., C. McLiesh and A. Shleifer A. (2007), "Private Credit in 129 Countries”, Journal of Financial Economics, Vol. 84(2), pp. 299-329.

Fink, G., P. Haiss and S. Hristoforova (2005), "Credit, Bonds and Stocks in Seven Large Economies”, available at http://fgr.wu-wien.ac.at/institut/ef/nexus.html.

Gerschenkron, A. (1962), “Economic Backwardness in Historical Perspective”, Harvard University Press.

Giovannini, A. and M. De Melo (1991), “Government Revenue from Financial Repression”, American Economic Review, Vol. 83, No. 4, pp. 953-963.

Gual, J. (1999), “Deregulation, Integration and Market Structure in the European Banking”, CEPR Discussion Paper, No. 2288.

Haslag, J. and J. Koo (1999), "Financial Repression, Financial Development and Economic Growth”, Federal Reserve of Dallas, Working Paper, No 99-02.

Hauner, D. (2008), “Public debt and financial development”, Journal of Development Economics, Vol. 88 (2), pp. 171-183.

Islam, N. (1995), “Growth Empirics: A Panel Data Approach”, Quarterly Journal of Economics, Vol. 110(4), pp. 1127-1170.

La Porta, R., F. Lopez de Silanes, A. Shleifer and R W. Vishny (1997), "Legal Determinants of External Finance”, Journal of Finance, Vol. 52(3), pp. 1131-50.

La Porta, R., F. Lopez de Silanes F., and A. Shleifer (2002), ”Government Ownership of Banks”, The Journal of Finance, Vol. 72 (1), pp. 265-301.

Levine, R. (2003), “More on Finance and Growth: More Finance, More Growth?”, Federal Reserve Bank of St. Louis Review, Vol. 85, pp. 31-46.

Levine, R. and S. Zervos (1998), “Stock Markets, Banks, and Economic Growth”, American Economic Review, Vol. 88(3), pp. 537-558.

Levine, R. N. Loayza and T. Beck (2000), "Financial Intermediation and Growth: Causality and Causes”, Journal of Monetary Economics, Vol. 46(1), pp. 31-77.

Mayer, C. and O. Sussman (2001), “The Assessment: Finance, Law and Growth”, Oxford Review of Economic Policy, Vol. 17(4), pp. 457-466. 
McKinnon, R. (1973), “Money and Capital in Economic Development”, Washington, DC, The Brooking Institution.

Mitchell, B.R. (2003), “International Historical Statistics 1750-2005”, New York, Palgrave Macmillan.

Pagano, M. and P. Volpin (2001), “The Political Economy of Finance”, Oxford Review of Economic Policy, Vol. 17(4), pp. 502-519.

Perotti, E. and E.L. Von Thadden (2005), “The Political Economy of Corporate Control”, mimeo.

Piluso, G. and R. Ricciuti (2008), "Fiscal Policy and the Banking System in Italy. Have Taxes, Public Spending and Banks been Procyclical in the Long-Run?”, Cesifo Working Paper, No. 2442.

Quy-Toan, Do and A. Levchenko (2004), "Trade and Financial Development", World Bank, Policy, Research Working Paper Series, Vol. 3347.

Rajan, R.G. and L. Zingales (1995), "What Do We Know From Capital Structure: Some Evidence From the International Data”, Journal of Finance, Vol. 50 (5), pp. 1421-1460.

Rajan, R.G. and L. Zingales (2003), "The Great Reversals: The Politics of Financial Development in the 20th Century", Journal of Financial Economics, Vol. 69(1), pp. 5-50.

Roubini, N. and X. Sala-i-Martin (1995), “A growth model of inflation, tax evasion, and financial repression”, Journal of Monetary Economics, Vol. 35(2), pp. 275-301.

Shaw, E. (1973), “Financial Deepening in Economic Development”, New York, Oxford University Press. 